\title{
Pelatihan dan Sosialisasi Pembuatan Deterjen Cair Ramah Lingkungan Pengganti Deterjen Sintetik
}

\author{
Muhammad Ma'arij Harfadli', Mega Ulimaz², Nadia Almira Jordan³ \\ ${ }^{1}$ Departemen Teknik Lingkungan, 2Departemen Perencanaan Wilayah dan Kota, \\ ${ }^{3}$ Departemen Arsitektur, Institut Teknologi Kalimantan \\ Jl. Soekarno Hatta km 15, Balikpapan, 76127, Indonesia
}

\begin{abstract}
ARTICLE INFO
Received: $2020-11-15$

Revised: 2020-12-20

Accepted: 2021-01-30

Keywords:

Eco-friendy, Liquid detergent, Production, Training

\section{ABSTRACT}

The dominance of the use of synthetic detergents is tends to be high, especially in RT 54 neighborhood Karang Joang Village, North Balikpapan. The use of packaged detergent that produce B3 waste is still unknown by the residents. In addition, the absence of waste management and particular disposal systems also contribute as a negative impact on the environment. The training and socialization activities for making environmentally friendly detergents were carried out to provide information about the basic ingredients for eco-friendly detergent using Methyl Ester Sulfonate (MES) as a vegetable surfactant, as well as to encourage participants to be able to make detergents independently. The method used in this activity is demonstrations by explaining the stages of manufacture. The process of making detergent is carried out through the preparation stage, the making process and recording in video, using simple tools and materials. Video demonstrations were published on social media so that the dissemination of information was wider than the initial target of the activity. Through this activity, the results obtained were that the stages of making detergents that were not too complicated, so it could be easily understood, especially with a video guide that could be accessed at any time.

(c) 2021 Published by University of Merdeka Malang. This is an open access article distributed under the CC BY-SA 4.0 license (https://creativecommons.org/licenses/by-sa/4.0/)

How to cite: Harfadli, M. M., Ulimaz, M., \& Jordan, N. A. (2021). Pelatihan dan Sosialisasi Pembuatan Deterjen Cair Ramah Lingkungan Pengganti Deterjen Sintetik. Abdimas: Jurnal Pengabdian Masyarakat Universitas Merdeka Malang, 6(1), 10-17. https://doi.org/10.26905/abdimas.v6i1.5025
\end{abstract}

\section{PENDAHULUAN}

Rencana Detail Tata Ruang (RDTR) Kota Balikpapan menyebutkan bahwa permukiman di Kelurahan Karang Joang direncanakan sebagai perumahan kepadatan tinggi (R2). Selain itu, berdasarkan RT/RW Kota Balikpapan tahun 2012-2032, pengembangan Sub Pusat Pelayanan Kota Balikpapan sebagai Kawasan Pusat Kota ke-2 adalah Kelurahan Karang Joang, Kecamatan Balikpapan Utara. Pertumbuhan kawasan sebagai pusat kota secara bertahap akan mengalami peningkatan aktivitas, fasilitas dan juga fungsinya dalam struktur kota. Salah satu aktivitas yang telah meningkat di Kelurahan Karang Joand sampai dengan tahun 2020 adalah permukiman dengan kepadatan yang bervariasi dan dihuni oleh masyarakat yang 


\section{Pelatihan dan Sosialisasi Pembuatan Deterjen Cair Ramah Lingkungan Pengganti Deterjen Sintetik}

Muhammad Ma'arij Harfadli, Mega Ulimaz, Nadia Almira Jordan

heterogen. Peningkatan intensitas kegiatan bermukim akan meningkatkan intensitas buangan, salah satunya adalah limbah deterjen. Sejalan dengan hal tersebut, pelaksanaan tentang pengaruh deterjen terhadap perairan (Taufik, 2006) menyebutkan penambahan beban pencemaran deterjen dalam perairan disebabkan oleh limbah domestrik dan kenaikan jumlah industri. Limbah deterjen merupakan sisah produk pembersih yang dapat diidentifikasi sebagai jenis limbah cair B3 (Putra et al., 2019). Deterjen merupakan bahan pencuci yang efektif karena didalamnya terkandung satu atau lebih surfaktan yang dibuat dari minyak bumi dan bahan kimia. Secara umum deterjen dapat berbentuk liquid, pasta, atau powder yang mengandung konstituen bahan aktif pada permukaannya dan konstituen bahan tambahan. Konstituen bahan aktif adalah berupa surfaktan yang merupakan singkatan dari surface active agents, yaitu bahan yang menurunkan tegangan permukaan suatu cairan dan di antar muka fasa (baik cair-gas maupun cair-cair) untuk mempermudah penyebaran dan pemerataan. Salah satu dampak negatif limbah diterjen adalah ketidakseimbangan lingkungan hidup.

Sampai dengan tahun 2019, strategi sistem pengolahan yang dikembangkan Kota Balikpapan adalah arahan dalam pengembangan teknis pengelolaan air limbah domestik dengan sistem setempat (on-site sanitation) dan sistem terpusat (off-site sanitation). Sistem pembuangan air limbah domestik rumah tangga di Kelurahan Karang Joang sendiri masih dilakukan dengan cara membuang langsung ke saluran perairan sekitar. Hal serupa juga ditemukan oleh beberapa pelaksanaan (Mu'min et al., 2020; Putra et al., 2019; Prasetyaningrum et al., 2017), yaitu belum tersedianya pengelolaan limbah B3 secara khusus. Selain itu, tidak terjadi proses pemilahan sampah B3 yang dilengkapi dengan fasilitas pengolahan limbah B3 untuk masyarakat. Hal ini disebabkan karena pada umumnya masyarakat Karang Joang menganggap bahwa deterjen bukan suatu bahan yang berbahaya dan tidak bersifat toksik, sehingga limbah cairnya dapat di buang langsung ke perairan. Selaras dengan pelaksanaan yang dilakukan di Kota Semarang (Prasetyaningrum et al., 2017), sebagian besar (58\%) responden rumah tangga belum memiliki pengetahuan yang baik tentang sampah rumah tangga yang mengandung B3. Kandungan sisa deterjen pada perairan disebut juga cukup mengganggu ekosistem air tidak hanya ikan, tetapi juga kerang, siputdan plankton (Komarawidjaja, 2004). Menurut Taufik (2006), pencemaran deterjen di perairan dapat berpengaruh pada berbagai organ ikan seperti kulit, insang, organ pencernaan, dan bahkan hati dan tingkat kerusakan yang timbul pada organ tersebut tergantung pada konsentrasi pencemaran dan waktu pemaparan.

Permasalahan yang dihadapi adalah kurangnya pengetahuan dan kesadaran masyarakat terhadap kelestarian lingkungan. Selain itu, peran masyarakat sangat rendah dalam upaya minimalisasi limbah B3 serta bergantung pada kapasitas pelayanan yang terbatas. Di sisi lain, produk deterjen berbasis bahan alam masih jarang ditemukan. Mayoritas produk masih menggunakan bahan sintetik deterjen dan bahan-bahan kimia seperti Sodium Lauryl Sulphate (SLS), Sodium Lauryl Ether Sulphate/Sodium Laureth Sulphate (SLES), dan Linier Alkyl Benzene. Bahan aktif sintetik ini memiliki efek negatif terhadap kulit manusia, karena berpotensi menimbulkan iritasi pada konsumen yang memiliki kulit sensitif. Bahan sintetik tersebut dapat diganti dengan bahan alami yaitu deterjen yang terbuat dari reaksi alami antara alkali (basa) misalnya $\mathrm{NaOH} / \mathrm{KOH}$ dengan minyak/lemak atau yang sering disebut dengan istilah saponifikasi. Methyl Ester Sulfonate (MES) merupakan surfaktan senyawa kimia yang digunakan sebagai bahan dasar untuk pembuatan detergen berbahan alami. Berdasarkan riset yang telah dilakukan (Lubis 
ABDIMAS: Jurnal Pengabdian Masyarakat Universitas Merdeka Malang Volume 6, No. 1, February 2021: 10-17

et al., 2012), emulsi yang dilakukan bersifat larut dalam minyak, sehingga bahan ini merupakan bahan yang tepat sebagai bahan dasar deterjen. Selain itu, kandungan nabati yang dimiliki MES juga menjadi alternatif yang lebih ramah lingkungan berkaitan dengan sisa produk pencucian. Bahan tersebut dapat mudah ditemukan dengan proses pembuatan yang relatif mudah dan dapat dilakukan di rumah.

Sasaran kegiatan pelatihan dan sosialisasi ini adalah masyarakat Perum BCA, Karang Joang, Kecamatan Balikpapan Utara, yang sebagian besar memiliki mata pencarian sebagai karyawan swasta. Kegiatan sosialisasi dilakukan untuk meningkatkan pengetahuan masyarakat, sehingga dapat mengenali dan menggunakan bahan-bahan ramah lingkungan dalam kegiatan rumah tangga sehari-hari. Hal tersebut sejalan dengan pelaksanaan yang dilakukan oleh (Agustina et al., 2018), yaitu sosialisasi yang minim dapat menghambat penyebaran informasi, sehingga akan dampak pada tingkat pemahaman masyarakat terhadap masalah, kendala serta solusi yang dihadapi masyarakat.

Program pelatihan ini selain diharapkan dapat menjadi usaha meminimalisir limbah cair B3, juga dapat memberikan peluang usaha kepada masyarakat, sehingga bisa meningkatkan perekonomian rumah tangga. Produk deterjen yang dihasilkan dapat digunakan untuk memenuhi kebutuhan rumah tangga ataupun dapat diperdagangkan ke masyarakat sekitar. Hal tersebut juga dikuatkan pada kegiatan pelatihan sejenis yang kemudian meningkatkan pemahaman masyarakat dan memberikan ide peluang usaha bagi rumah tangga (Tanjung, 2017).

\section{METODE}

Pelatihan dan sosialisasi dilakukan dengan metode ceramah dan demonstrasi, yaitu peragaan dan penunjukkan proses, keadaan dan kondisi tertentu yang sedang dilakukan untuk memberikan pembelajaran atau pemahaman kepada peserta. Metode ini digunakan untuk menyajikan cara melakukan sesuatu, dalam hal ini adalah cara membuat deterjen cair ramah lingkungan. Secara umum, metode demonstrasi dipilih untuk memberikan pengertian yang efektif, karena peserta dapat melihat secara langsung tahapan dan situasi benda yang diperagakan dan dapat langsung diterapkan (Huda, 2013). Berdasarkan riset yang dilakukan pada proses pembelajaran, metode demonstrasi menunjukkan pengaruh terhadap peningkatan nilai rata-rata pada tes peserta, sehingga berdampak positif terhadap peningkatan presetasi (Suhendro et al., 2018). Demonstrasi dilakukan melalui video yang dipublikasikan pada grup pembicaraan di RT 54 dan juga platform daring, yang dapat diakses oleh seluruh peserta dan masyarakat secara umum. Melalui sarana publikasi tersebut, tim pelaksana tidak hanya memberikan informasi satu arah, tapi juga memberikan kemungkinan untuk tanya jawab dan bertukar informasi terkait konten penyajian.

Sasaran peserta kegiatan pelatihan dan sosialisasi pembuatan deterjen ramah ligkungan adalah ibu rumah tangga di Perumahan BCA, RT 54, Kelurahan Karang Joang. Adapun yang menjadi narasumber dalam kegiatan ini adalah para dosen dan mahasiswa yang memiliki pemahaman dalam pengelolaan limbah cair rumah tangga. Sebelum melaksanakan pelatihan, tahapan persiapan yang dilakukan oleh tim antara lain: (1) Menyusun daftar kebutuhan alat dan bahan pendukung untuk kegiatan pelaksanaan sosialisasi; (2) Melakukan perizinan kepada Ibu Bendahara RT 54, yaitu menyampaikan maksud dan tujuan kegiatan, penentuan sasaran dan metode pelatihan; (3) Melakukan penjaringan informasi pengetahuan 
tentang B3 dengan memberikan daftar pertanyaan untuk memperoleh gambaran pengetahuan jenis produk B3 rumah tangga; (4) Mempersiapkan alat dan bahan. Alat yang dibutuhkan terdiri dari gayung, pengaduk, panci, kompor, penyaring, dan ember. Sedangkan bahan yang dibutuhkan terdiri dari MES (Metil Ester Sulfonat) yang terbuat dari bahan nabati, $500 \mathrm{gr}$ garam, $50 \mathrm{ml}$ camperlan (foam booster) sebagai bahan penambah busa, $50 \mathrm{ml}$ pewarna, $50 \mathrm{ml}$ pewangi, $3 \mathrm{sdt}$ EDTA (Ethylenediaminetetraacetic acid) sebagai pengawet sabun, dan air.

\section{HASIL DAN PEMBAHASAN}

Pelatihan dan sosialisasi dilakukan pada bulan Oktober tahun 2020 di lingkungan RT 54 Kelurahan Karang Joang. Berkenaan dengan pandemi COVID-19 yang masih terjadi di Kota Balikpapan, pelatihan dilakukan secara tidak langsung, yaitu menggunakan video peragaan. Hal tersebut dilakukan untuk meminimlisir kegiatan berkumpul warga dan interaksi yang terlalu dekat antar peserta. Sebelumnya, tim pelaksana telah mendapatkan gambaran awal pengetahuan peserta mengenai limbah B3. Berdasarkan hasil penjaringan informasi melalui daftar pertanyaan, diperoleh bahwa tingkat pemahaman ibu-ibu di RT 54 terhadap 36 jenis produk B3 rumah tangga yaitu sekitar 69\%. Di sisi lain, 31\% produk belum dikenal sebagai produk B3.

Proses selanjutnya adalah persiapan pembuatan video demosntrasi pembuatan deterjen yang dilakukan oleh tim pelaksana. Alat yang digunakan merupakan alat yang mudah ditemukan, sehingga proses persiapan dilakukan dengan menggunakan alat yang telah tersedia di rumah tim. Persiapan lokasi demonstrasi dilakukan dengan pemasangan spanduk kegiatan untuk menginformasikan judul, waktu dan memperkenalkan tim pelaksana.
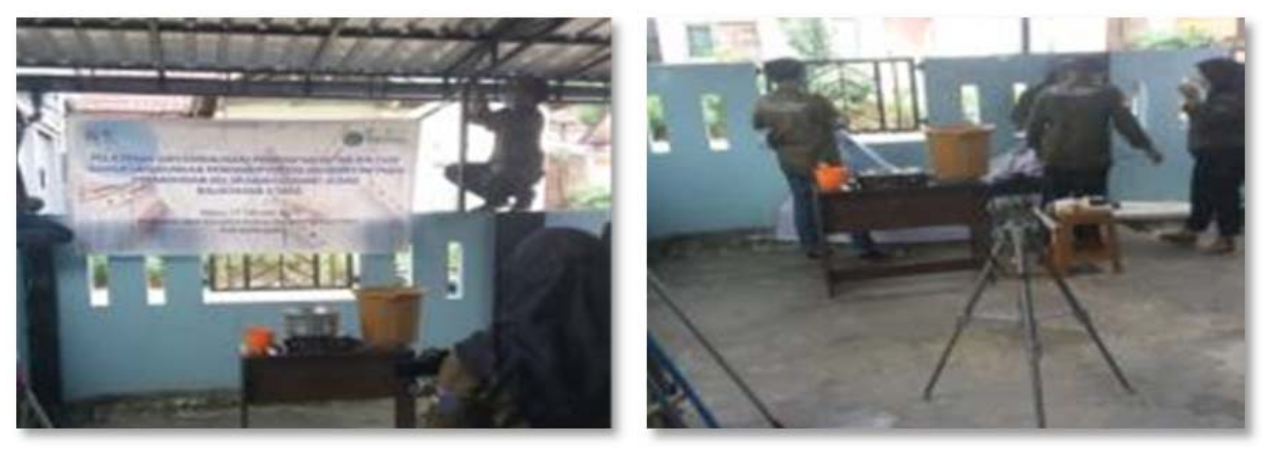

Gambar 1. Proses persiapan pembuatan video peragaan

\section{Tahapan pelaksanaan}

Pelaksanaan demontrasi pembuatan deterjen dilakukan oleh tim dengan cara memperagakan proses sabun deterjen. Sebelumnya, tim pelaksana memberikan penjelasan singkat terkait jenis dan karakteristk bahan yang digunakan. Bahan-bahan dan peralatan yang digunakan untuk proses pembuatan sabun cair dan sabun transparan disediakan oleh tim pelaksana yang terdiri dari dosen dan mahasiswa. Proses pembuatan deterjen ramah lingkungan diawali dengan mencairkan MES ke salam 5 liter air di 
ABDIMAS: Jurnal Pengabdian Masyarakat Universitas Merdeka Malang

Volume 6, No. 1, February 2021: 10-17

dalam panci dengan cara dipanaskan sampai larutan mencair sempurna. Pada wadah yang berbeda, garam dilarutkan ke dalam 5 liter air sampai cairan menjadi homogen.
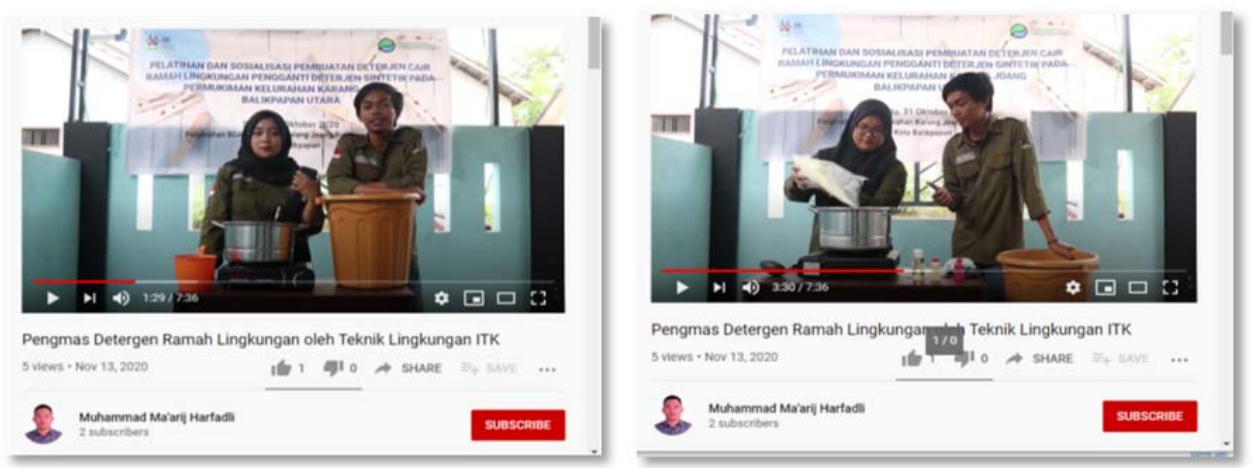

Gambar 2. Proses pembuatan deterjen pada video

Selanjutnya, tanpa menunggu sampai mendidih, larutan MES yang sudah larut sempurna dicampurkan ke dalam larutan garam di dalam ember. Campuran diaduk secara perlahan sampai tercampur rata dan mengental. Selanjutnya, masukkan foam booster dan EDTA ke dalam campuran MES dan garam, dan aduk hingga campuran merata. Tahap berikutnya adalah memasukkan 10 liter air secara bertahap sembari diaduk secara perlahan. Pengadukan diusahakan tidak terlalu cepat, untuk meminimalisir timbulnya busa. Jika timbul busa, dapat digunakan penyaring untuk menghilangkan busa. Selanjutnya, jika sudah tercampur sempurna, masukkan pewarna dan pewangi untuk memberikan aroma deterjen dan warna. Setelah semua bahan tercampur, campuran kemudian didiamkan selama 2 jam agar campuran menjadi bening dan homogen, kemudian deterjen siap digunakan. Produk deterjen yang dapat dihasilkan dari proses dan sejumlah bahan yang disiapkan adalah 25 botol dengan ukuran 1 liter.
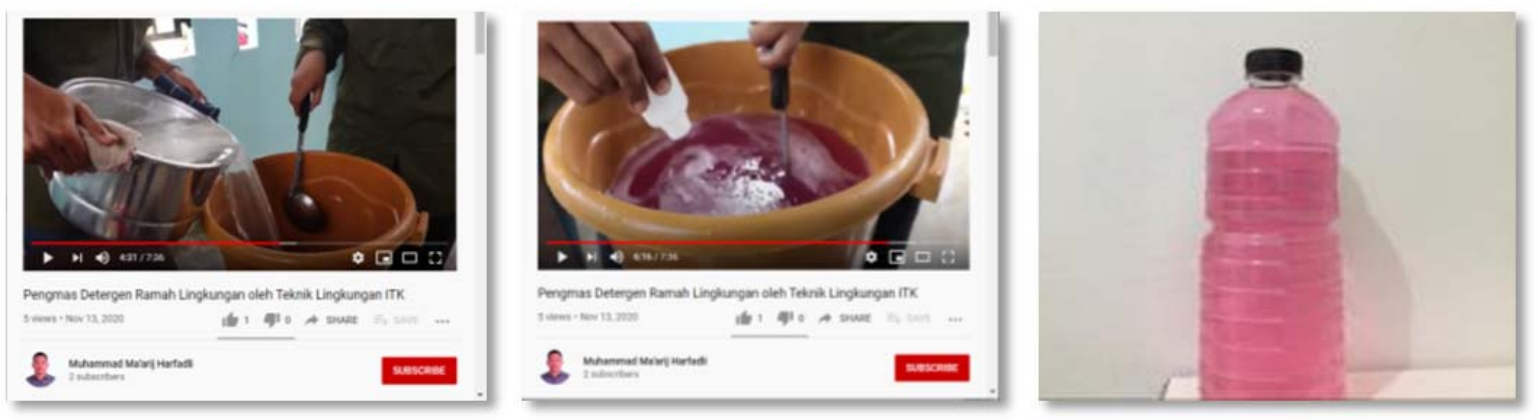

Gambar 3. Proses akhir pembuatan deterjen pada video

Gambar 4. Produk deterjen

Proses pembuatan deterjen direkam dan disajikan pada video yang dipublikasikan pada platform youtube pelaksana. Penjelasan diberikan oleh tim terkait pemilihan bahan dasar untuk menghasilkan deterjen dengan karakter yang ramah lingkungan dan mudah didegradasi, kemudian dilanjutkan dengan demonstrasi pembuatan. 

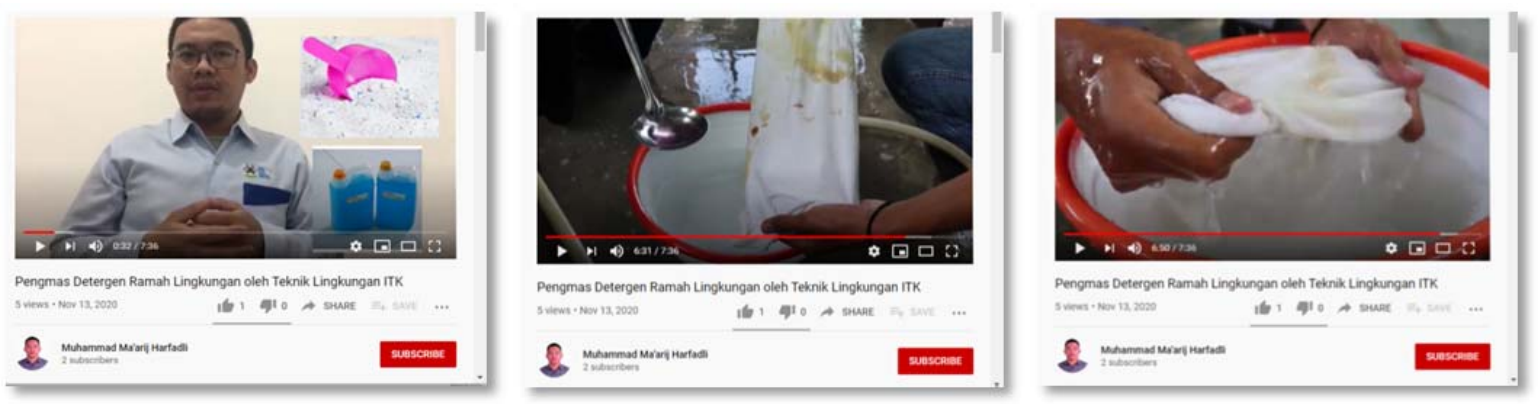

Gambar 5. Penjelasan awal tentang bahan dasar pembuatan deterjen

Gambar 6. Demonstrasi uji coba produk

Pada video yang telah dipublikasikan, tim pelaksana juga melakukan demonstrasi pengujian deterjen yang telah dibuat. Uji coba dilakukan sebagai teknik pembuktian terhadap keandalan produk yang telah dibuat. Proses uji doba deterjen dilakukan dengan mencampurkan deterjen pada air, kemudian mencelupkan dan mengosok kain kotor. Selanjutnya, membilas kain yang telah dicuci dengan deterjen tersebut.
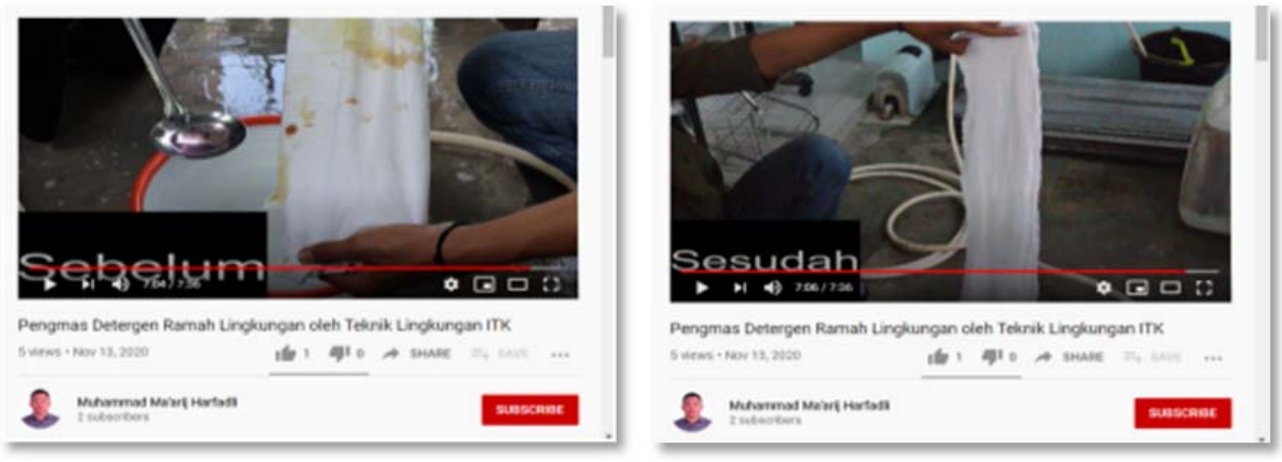

Gambar 7. Pembuktian keandalan produk

Pada tahap selanjutnya, tim pelaksana menyebarkan tautan video melalui grup percakapan RT 54 Kelurahan Karang Joang sebagai media penyebaran informasi. Informasi tersebut diterima dengan baik oleh warga dan terjadi diskusi dengan tim pelaksana.

Proses pelaksanaan demontrasi pembuatan deterjen ramah lingkungan dilakukan dengan alat yang mudah ditemukan di sekitar, dan bahan yang mudah ditemukan atau dibeli. Berdasakran uji coba yang telah dilakukan tim pelaksana, deterjen ramah lingkungan dengan bahan yang telah disediakan terbilang efektif untuk membersihkan noda dan dapat digunakan sebagai produk pembersih. Tahapan pembuatan yang tidak terlalu rumit dan panjang menjadi salah satu kelebihan pembuatan deterjen ini. Proses yang sederhana dapat dilakukan oleh peserta sendiri di rumah masing-masing. Selain itu, bahan yang diketahui secara langsung oleh msyarakat dapat menjamin kemanan produk. 
ABDIMAS: Jurnal Pengabdian Masyarakat Universitas Merdeka Malang

Volume 6, No. 1, February 2021: 10-17

\section{SIMPULAN DAN SARAN}

\section{Simpulan}

Kegiatan pelatihan dengan menggunakan metode demonstrasi menjadi suatu kegiatan yang dapat dengan lebih mudah memberikan pemahaman langsung dan dapat memandu peserta untuk melakukan pembuatan deterjen. Keberadaan video yang dapat ditonton oleh masyarakat secara berulang dan menyebar juga memperluas jangkaun penyebaran informasi tidak hanya pada lingkungan lokasi kegiatan saja. Secara prinsip, penggunaan MES sebagai bahan dasar deterjen ramah lingkungan merupakan salah satu pilihan bagi ibu rumah tangga untuk secara mandiri memastikan keamanan produk pembersih di rumah. Selain itu, pemanfaatan deterjen ramah lingkungan juga menjadi langkah rumah tangga untuk berkontribusi terhadap keselamatan lingkungan. Berdasarkan kegiatan pembuatan deterjen secara mandiri, pelatihan pembuatan deterjen ramah lingkungan tidak hanya dapat membantu rumah tangga untuk menggunakan bahan-bahan yang tidak berdampak negatif bagi lingkungan, tetapi juga dapat mendorong ibu rumah tangga untuk memproduksi deterjen yang dapat menjadi produk usaha rumah tangga. Kegiatan pengbdian kepada masyarakat yang melibatkan masyarakat secara langsung pada prinsipnya tidak hanya dapat menjadi media penyaluran hasil penelitian, pengetahuan dan eksperimen para akademisi, tetapi juga dapat menjadi pelatihan wirausaha bagi mitra atau sasaran kegiatan.

\section{Saran}

Adapun saran bagi pelaksana kegiatan selanjutnya, diperlukan pula evaluasi kegiatan yang berfokus pada kemajuan mitra atau sasaran kegiatan, terutama dalam mengatasi permasalahan yang dihadapi. Minimnya tatap muka secara langsung pada kondisi pandemi dapat diantisipasi pelaksana salah satunya melalui aplikasi percakapan. Melalui evaluasi tersebut, pelaksana tidak hanya dapat mengetahui keberhasilan kegiatan yang dilakukan, tetapi dimungkinkan juga untuk mendapatkan masukan kegiatan selanjutnya.

\section{Ucapan Terima Kasih}

Penulis mengucapkan terima kasih kepada Lembaga Pelaksanaan dan Pengabdian kepada Masyarakat Institut Teknologi Kalimantan atas pendanaan yang diberikan, sehingga penulis dapat menyelesaikan kegiatan pengabdian masyarakat dan publikasi hasil kegiatan. Selain itu, penulis juga mengucapkan terima kasih kepada Ketua RT 54 sebagai mitra yang telah bersedia turut mendukung kegiatan pengabdian kepada masyarakat terlaksana dengan baik.

\section{DAFTAR PUSTAKA}

Agustina, Z. A., Laksmiarti, T., \& Effendi, D. E. (2018). Pemilihan metode sosialisasi sebagai upaya peningkatan kepesertaan Badan Penyelenggara Jaminan Sosial (BPJS) mandiri. Media Litbangkes, 28(1), 33-40. https://doi.org/10.22435/mpk.v28i1.7638.33-38

Huda, M. (2013). Model-Model Pengajaran dan Pembelajaran. Yogyakarta: Pustaka Belajar. 
Komarawidjaja, W. (2004). Kontribusi Limbah Deterjen Terhadap Status kehidupan perairan di DAS Citarum Hulu. Jurnal Teknologi Lingkungan, 5(3), 193-197.

https://doi.org/10.29122/jtl.v5i3.315

Lubis, E. H., Hendra, W., \& Lestari, N. (2012). Mempelajari ekstraksi dan stabilitas total karotenoid, á dan â cryptoxanthin dalam ekstrak buah merah (Pandanus conoideus, Lamk). Jurnal Riset Teknologi Industri, 6(12), 11-19. http://dx.doi.org/10.26578/jrti.v6i12.1517

Mu'min, M., Mizwar, A., \& Mahyudin, R. P. (2020). Studi pola pengelolaan sampah B3 rumah tangga di Tabuk, Kertak Hanyar dan Gambut). Jernih: Jurnal Tugas Akhir Mahasiswa, 3(1), 61-68.

Prasetyaningrum, N. D. K., Joko, T., \& Dewanti, N. A. Y. (2017). Kajian timbulan sampah Bahan Berbahaya Dan Beracun (B3) rumah tangga di Kelurahan Sendangmulyo Kecamatan Tembalang Kota Semarang. Jurnal Kesehatan Masyarakat (JKM), 5(5), 766-775.

Putra, T. I., Setyowati, N., \& Apriyanto, E. (2019). Identifikasi jenis dan pengelolaan limbah bahan berbahaya dan beracun rumah tangga: Studi kasus Kelurahan Pasar Tais Kecamatan Seluma Kabupaten Seluma. Naturalis: Jurnal Penelitian Pengelolaan Sumber Daya Alam dan Lingkungan, 8(2), 49-61. https://doi.org/10.31186/naturalis.8.2.9209

Suhendro, S., Pargito, P., \& Widodo, S. (2018). Pengaruh metode demonstrasi dan metode ceramah terhadap hasil belajar geografi di SMAN 3 Metro. Jurnal Penelitian Geografi Universitas Lampung, 6(3), 1-13.

Tanjung, D. A. (2017). Pelatihan pembuatan sabun cair dan shampoo pencuci mobil. Jurnal Prodikmas: Hasil Pengabdian Masyarakat, 2(1), 41-45. https://doi.org/10.30596/jp.v2i1.1761

Taufik, I. (2006). Pencemaran deterjen dalam perairan dan dampaknya terhadap organisme air. Media Akuakultur, 1(1), 25-32. http://dx.doi.org/10.15578/ma.1.1.2006.25-32 